4th National Seminar on Guidance and Counseling (SNBK 2019) and Workshop on

Pedagogical Theory and Practice (WTPP 2019)

SHEs: Conference Series 2 (2) (2019) 34 - 39

\title{
The Impact of Microagression in Counseling on The Mental Health of Students
}

\section{Layyinatus Syifa}

Universitas Negeri Semarang

syifalayyinatus@students.unnes.ac.id

\section{Article History}

accepted 01/11/2019

approved 11/11/2019

published 31/12/2019

\begin{abstract}
This article examines the microagressions carried out by counselors in the counseling process that have an impact on the mental health of students. With a literature study the author tries to identify the forms of microagression, the impact of microagression in the counseling process, and strategies that can be done to overcome microagression. The background of this writing is based on the many stereotypes that appear in society towards certain groups viewed from the origin, race, religion, gender, sexual orientation. The writing of this article is expected to help guide efforts to recognize, minimize and respond to microagress in the counseling process.
\end{abstract}

Keywords: microagressions, counseling, mental health

\section{Abstrak}

Artikel ini mengkaji tentang mikroagresi yang dilakukan oleh konselor dalam proses konseling yang berdampak pada kesehatan mental peserta didik. Dengan studi literatur penulis mencoba untuk mengidentifikasi bentuk-bentuk mikroagresi, dampak mikroagresi dalam proses konseling, dan strategi yang dapat dilakukan untuk mengatasi mikroagresi. Latar belakang dari penulisan ini didasarkan pada banyaknya stereotip yang muncul di masyarakat terhadap kelompok tertentu dilihat dari asal, ras, agama, gender, orientasi seksual. Dari penulisan artikel ini diharapkan dapat membantu memandu upaya-upaya untuk mengenali, meminimalkan, dan menghindari mikroagresi dalam proses konseling yang berdampak pada kesehatan mental peserta didik.

Kata kunci: mikroagresi, konseling, kesehatan mental

Social, Humanities, and Education Studies (SHEs): Conference Series https://jurnal.uns.ac.id/shes

p-ISSN 2620-9284

e-ISSN 2620-9292 


\section{PENDAHULUAN}

Dalam lingkup sekolah, setiap siswa memiliki perbedaan antar siswa satu dengan lainnya, dari sisi suku asal, etnis, budaya, agama, status social, jenis kelamin dan orientasi seksual. Perbedaan tersebut dapat memicu terjadinya konflik. Sama halnya dalam proses konseling, pertemuan antar konselor dan konseli yang berbeda latar belakang dapat menjadi ancaman timbulnya masalah sehingga menghambat proses konseling. Menurut Robinson, Zigler, \& Gallagher (Stambaugh \& Ford, 2015), ketika setiap individu berbeda secara signifikan dari populasi umum, baik dalam kepercayaan, kemampuan, perbedaan budaya, ras / etnis, atau status sosial, mereka mungkin lebih rentan terhadap kesalahpahaman, kurangnya kecocokan, dan mikroagresi. Misalnya seorang konselor beragama Islam dari suku Jawa menghadapi siswa (konseli) gay, beragama Kristen dan berasal dari suku Batak. Maka konselor perlu memahami akan latar belakang konseli tersebut dengan pengalaman konseli yang melibatkan orientasi seksual, agama dan asal suku. Apabila konselor gagal untuk mengenali pengalaman konseli tersebut maka konseli merasa tidak dipahami, bingung dan perasaan lain sehingga merusak hubungan terapeutik konselor dengan konseli, dan bisa berdampak pada kesalahan dalam pengambilan keputusan(Houshmand, Spanierman, \& De Stefano, 2017).

Kegagalan konselor dalam memahami konseli dapat terwujud dalam bentuk komentar, sikap, tindakan yang dilakukan konselor kepada konseli yang tidak pantas atau menyakitkan yang disebut sebagai mikroagresi. Mikroagresi dapat dilakukan dengan sengaja dan tidak sengaja, bisa halus dan terang-terangan, sering didasarkan pada asumsi tentang ras/etnis, jenis kelamin dan pendapatan ( Valencia, 2010). Menurut Sue \& Sue (2016) mikroagresi dapat didefinisikan sebagai pertukaran singkat dengan mengirim pesan-pesan yang merendahkan ke kelompok sasaran, seperti orang-orang berwarna; minoritas agama; wanita; orang cacat; dan individu gay, lesbian, biseksual, dan transgender. Mikroagresi nampak tidak menjadi masalah dan tidak berbahaya, namun secara kumulatif bisa sangat berbahaya bagi kesehatan fisik dan mental seseorang ( Sue \& Sue, 2016).

Menurut Strong (Sue \& Sue, 2016), kredibilitas seorang konselor sangat penting dalam proses konseling, yang akan menentukan apakah konseli akan mengakhiri atau melanjutkan konseling. Kredibilitas terdiri dari dua dimensi yaitu keahlian dan kepercayaan. Keahlian erkaitan dengan ilmu pengetahuan, pengalaman dan ketrampilan sedangkan kepercayaan adalah komponen motivasi yang mencakup kepercayaan, kejujuran, dan keaslian. Meskipun keahlian selalu penting, kepercayaan dapat menjadi pusat konseling dan terapi multikultural. Konseling yang efektif dapat terlaksana ketika konselor dan klien mampu membentuk hubungan kerja, aliansi terapeutik, atau beberapa bentuk koalisi positif. Dalam praktik kesehatan mental ada kepercayaan universal bahwa konseling yang efektif dan bermanfaat mengharuskan klien mempercayai penasihat mereka (Corey, 2012).

Penelitian menunjukkan bahwa persepsi konseli tentang mikroagresi rasial berhubungan negatif dengan aliansi terapeutik (Owen et al., 2014). Penelitian lain mendukung temuan serupa ketika melayani dengan konseli LGBT dimana aliansi dan proses terapeutik telah terbukti berkurang dan secara negatif dipengaruhi oleh mikroagresi orientasi seksual: "konsekuensi afektif dari orientasi seksual agresi mikro adalah klien merasa tidak nyaman, bingung, tidak berdaya, tidak terlihat, ditolak, dan dipaksa atau dimanipulasi untuk mematuhi perawatan (Shelton \& Delgado-Romero, 2013).

Hasil penelitian diatas memunculkan dilema dalam proses konseling sebab konselor yang seharusnya bisa membantu konseli untuk kesejahteraan semua kelompok, objektif, melihat masalah secara internal. Namun, konselor justru memiliki bias, stereotip, dan prasangka yang membahayakan bagi siswa sebagai konseli. 
Menurut penelitian yang dilakukan oleh Owen et al (2010) menunjukkan bahwa prasangka dan bias terus dimanifestasikan dalam proses konseling.

Sesuai dengan kode etik ACA (2014) bahwa perlunya kompetensi budaya konselor, termasuk kesadaran mereka akan bias pribadi dan pandangan dunia budaya klien/konseli mereka. Sebagai konselor perlu memahami bentuk perilaku, sikap, ucapan dan tindakan yang termasuk dalam mikroagresi sehingga dapat menghindarinya dan meminimalisir dampak buruk bagi kesehetan mental siswanya (konseli).

\section{Mikroagresi}

\section{PEMBAHASAN}

Menurut Sue et al (Sue \& Sue, 2016) mikroagresi adalah penghinaan verbal atau perilaku sehari-hari yang singkat dan umum, baik disengaja atau tidak disengaja, yang mengkomunikasikan penghinaan dan penghinaan ras yang negatif, penghinaan,yang berpotensi memiliki dampak psikologis yang berbahaya atau tidak menyenangkan pada orang atau kelompok sasaran. Dalam konseling, mikroagresi dapat terjadi ketika konselor dan siswa sebagai konseli memiliki perbedaan yang cukup signifikan,seperti perbedaan ras/suku asal, agama, kelas social, orientasi seksual, jenis kelamin, kecacatan fisik, dan umur.

Secara umum mikroagresi dapat diidentifikasi sebagai berikut (a) cenderung halus, tidak disengaja, dan tidak langsung; (b) sering terjadi dalam situasi di mana ada penjelasan alternatif; (c) mewakili keyakinan dan sikap bias yang tidak disadari dan mendarah daging; dan (d) lebih mungkin terjadi ketika orang berpura-pura tidak melihat perbedaan, dengan demikian menyangkal bahwa ras, jenis kelamin, orientasi seksual, agama, atau kemampuan ada hubungannya dengan tindakan mereka (Sue, Capodilupi, et al., 2008)

Bentuk-bentuk mikroagresi menurut Sue \& Sue (2016) dapat dibagi menjadi 3, yaitu:

\section{1) Microassault}

Istilah microassault mengacu pada serangan verbal, nonverbal, atau lingkungan yang terang-terangan dimaksudkan untuk menyampaikan sentimen diskriminatif dan bias. Gagasan ini terkait dengan rasisme terbuka, seksisme,heteroseksisme, kemampuan, dan diskriminasi agama di mana individu dengan sengaja menyampaikan pesan menghina kepada kelompok sasaran.

2) Microinsult

Microinsult adalah perilaku yang tidak disengaja atau komentar verbal yang menyampaikan kekasaran atau ketidakpekaan atau merendahkan warisan ras / identitas seseorang, identitas gender, agama, kemampuan, atau identitas orientasi seksual. Meskipun berada di luar tingkat kesadaran, penghinaan halus ini ditandai dengan pesan tersembunyi yang menghina.

3) Microinvalidation

Microinvalidations adalah komentar atau perilaku verbal yang mengecualikan, meniadakan, atau mengabaikan pikiran psikologis, perasaan, atau realitas pengalaman dari kelompok target. Seperti hasil mikro, mereka tidak disengaja dan biasanya di luar kesadaran pelaku. 
4th National Seminar on Guidance and Counseling (SNBK 2019) and Workshop on

Pedagogical Theory and Practice (WTPP 2019)

SHEs: Conference Series 2 (2) (2019) 34 - 39

Tabel 1. Contoh Bentuk Mikroagresi dalam Konseling

\begin{tabular}{|c|c|c|}
\hline Tema & Mikroagresi & Pesan \\
\hline \multirow[t]{2}{*}{$\begin{array}{l}\text { Menetapkan } \\
\text { kecerdasan siswa } \\
\text { berdasarkan ras, jenis } \\
\text { kelamin. }\end{array}$} & $\begin{array}{l}\text { Seorang } \\
\text { sekolah bereaksi terkejut } \\
\text { ketika seorang siswa } \\
\text { dari Asia mengalami } \\
\text { kesulitan dalam } \\
\text { matematika dasar. }\end{array}$ & $\begin{array}{l}\text { Semua siswa asia pintar } \\
\text { dalam matematika. }\end{array}$ \\
\hline & $\begin{array}{l}\text { Konselor sekolah } \\
\text { bereaksi dengan terkejut } \\
\text { bahwa seorang siswa } \\
\text { perempuan mendapat } \\
\text { nilai tinggi pada } \\
\text { pelajaran matematika. }\end{array}$ & $\begin{array}{lr}\text { Bukan hal yang wajar } \\
\text { bila siswa perempuan } \\
\text { pintar } & \text { dalam } \\
\text { matematika. } & \end{array}$ \\
\hline 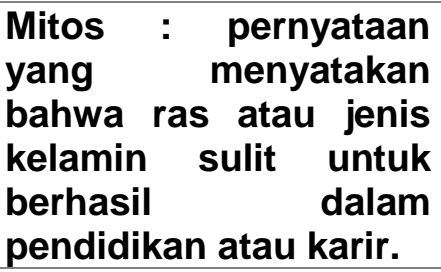 & $\begin{array}{l}\text { Konselor sekolah } \\
\text { memberi tahu siswa kulit } \\
\text { hitam bahwa "Jika Anda } \\
\text { bekerja keras, Anda bisa } \\
\text { berhasil seperti orang } \\
\text { lain." }\end{array}$ & $\begin{array}{l}\text { Siswa berkulit hitam } \\
\text { tidak mempunyai } \\
\text { kompetensi, sehingga } \\
\text { perlu berusaha lebih } \\
\text { untuk sama dengan } \\
\text { orang lain. }\end{array}$ \\
\hline $\begin{array}{l}\text { Konselor menerima } \\
\text { siswa LGBT }\end{array}$ & 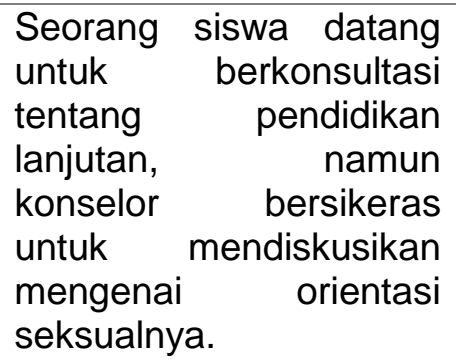 & $\begin{array}{l}\text { Orientasi seksual } \\
\text { mewakili patologi. }\end{array}$ \\
\hline Gaya Komunikasi & $\begin{array}{l}\text { Seorang siswa suku } \\
\text { Batak berbicara dengan } \\
\text { keras, emosional, dan } \\
\text { konfrontatif dalam sesi } \\
\text { konseling. Konselor } \\
\text { mendiagnosisnya } \\
\text { dengan gangguan } \\
\text { kepribadian ambang. }\end{array}$ & $\begin{array}{l}\text { Asimilasi dengan budaya } \\
\text { dominan. }\end{array}$ \\
\hline
\end{tabular}

\section{Dampak Mikroagresi Bagi Kesehatan Mental Siswa}

Penelitian yang dilakukan oleh Nadal et al (Nadal, Griffin, Wong, Hamit, \& Rasmus, 2014) menunjukkan bahwa ada hubungan negatif yang signifikan antara mikroagresi rasial dan kesehatan mental. Individu yang merasakan dan mengalami mikroagresi rasial dalam kehidupan mereka cenderung menunjukkan gejala kesehatan mental yang negatif, seperti depresi, kecemasan, pengaruh negatif (atau pandangan negatif dunia), dan kurangnya kontrol perilaku. Selain mikroagresi rasial, bentuk mikroagresi lain seperti mikroagresi sebab kelas social, mikroagresi pada kelompok terpinggirkan juga memberikan dampak negative bagi kesehatan mental.

Sependapat dengan hasil penelitian diatas, Gina et al (2019) mengungkapkan bahwa mikroagresi memiliki dampak negatif pada kesehatan mental dan fisik. Maka dari itu ia berpendapat perlu untuk melakukan investigasi terhadap evolusi agresif yang 
dialami oleh orang berwarna, wanita, dan orang LGBTQ. Hasil dari studi menemukan bahwa mikroagresi berdampak negatif terhadap gejala-gejala yang berkaitan dengan depresi, kegelisahan, dan trauma; perilaku-perilaku kesehatan seperti kecanduan alkohol, penggambaran psikologis, dan konstruksi psikologis seperti pencapaian harga diri, pandangan dunia, dan prestasi akademik.

Dari penjelasan diatas nampak bahwa mikroagresi dapat memberikan dampak buruk bagi siswa (konseli). Terutama bila mikroagresi dialami secara berulang dan terus menerus baik dari lingkungan maupun dari professional kesehatan mental/ konselor. Diantara dampak buruk dari mikroagresi yaitu kecemasan, merasa tidak dihargai, sulit percaya terhadap orang lain, kegelisahan, bahkan depresi.

\section{Implikasi Bagi Konselor di Sekolah}

1) Konselor perlu menyadari akan adanya perbedaan dalam setiap pertemuan dengan siswa sebagai konseli, perbedaan itu meliputi ras, gender, orientasi seksual merupakan kenyataan yang ada dalam kehidupan berkelompok yang beragam secara budaya.

2) Konselor perlu menyadari bahwa mikroagresi sering terjadi dalam kehidupan sehari-hari baik dilakukan dengan sengaja atau tidak, disadari atau tidak. Hendaknya mikroagresi tidak terjadi dalam proses konseling karena akan menghambat konseling yang efektif.

3) Konselor perlu memperluas wawasan, kompetensi terkait pandangan mengenai budaya lain, realitas sosiokultural, dan tidak berprasangka atau mengambil kesimpulan pandangan kelompok tertentu.

4) Jika mendapatkan konseli yang berbeda secara budaya, konselor perlu menunjukkan sikap terbuka dan menerima konseli dengan berbagai kondisi.

\section{SIMPULAN}

Mikroagresi merupakan suatu penghinaan dalam bentuk perilaku, sikap, ucapan baik disengaja maupun tidak disadari ataupun tidak yang berkenaan dengan ras, jenis kelamin, dan orientasi seksual, seperti transgender, biseksual, ketidakcocokan gender, kemampuan, dan agama. Hal ini bisa terjadi di setiap lingkungan, tak terkecuali dilingkungan sekolah. Perlu kesadaran konselor akan ragam latar belakang siswa yang ada disekolah, sehingga ketika bertemu dalam proses konseling mampu menerima dan melayani siswa dengan baik dalam rangka membantu mengembangkan potensinya.

Mikroagresi dapat menyebabkan dampak buruk bagi kesehatan mental siswa, diantaranya cemas, gelisah, merasa tidak dihargai bahkan depresi. Jenis dari mikroagresi bermacam-macam, ada mikroagresi rasial, gender, agama, LGBTQ. Untuk penelitian selanjutnya dapat dilakukan seberapa besar setiap macam mikroagresi dapat memberikan dampak kesehatan mental.

\section{DAFTAR PUSTAKA}

American Counseling Association. (2014). ACA code of ethics. Alexandria, VA: Author. Corey, G. (2012). Theory and practice of counseling and psychotherapy, 9th ed. Belmont, CA: Brooks/Cole.

Gina C.Torino, et al. (2019). Everything You Wanted to Know About Microaggressions but Didn't Get a Chance to Ask. WILEY: New Delhi.

Houshmand, S., Spanierman, L. B., \& De Stefano, J. (2017). Racial Microaggressions: a Primer with Implications for Counseling Practice. International Journal for the Advancement of Counselling, 39(3), 203-216. https://doi.org/10.1007/s10447-0179292-0 
SHEs: Conference Series 2 (2) (2019) 34 - 39

Nadal, K. L., Griffin, K. E., Wong, Y., Hamit, S., \& Rasmus, M. (2014). The impact of racial microaggressions on mental health: Counseling implications for clients of color. Journal of Counseling and Development, 92(1), 57-66. https://doi.org/10.1002/j.1556-6676.2014.00130.x

Owen, J., Tao, K., \& Rodolfa, E. (2010). Microaggressions and women in short-term therapy: Initial evidence. Counseling Psychologist, 38(7), 923-946.

Owen, J., Tao, K. W., Imel, Z. E., Wampold, B. E., \& Rodolfa, E. (2014). Addressing racial and ethnic microaggressions in therapy. Professional Psychology: Research and Practice, 45(4), 283- 290.

Shelton, K., \& Delgado-Romero, E. A. (2013). Sexual orientation microaggressions: The experience of lesbian, gay, bisexual, and queer clients in psychotherapy. Psychology of Sexual Orientation and Gender Diversity, 1(S), 59-70

Stambaugh, T., \& Ford, D. Y. (2015). Microaggressions, multiculturalism, and gifted individuals who are black, hispanic, or low income. Journal of Counseling and Development, 93(2), 192-201. https://doi.org/10.1002/j.1556-6676.2015.00195.x

Sue, D. W., Capodilupo, C. M., \& Holder, A.M.B. (2008). Racial microaggressions in the life experience of Black Americans. Professional Psychology: Research and Practice, 39, 329-336. doi: 10.1037/0735-7028.39.3.329

Sue \& Sue. (2016). Counseling Culturally in Diverse. $7^{\text {th }}$ Edition. Wiley: New Jersey.

Valencia, R. R. (2010). Chicano students and the courts: The Mexican American legal struggle for educational equality. New York: New York University Press. 